ven und kulturellen Kontext s. 143-168. Berliini: De Gruyter.

Grass, Günter 1995: Ein weites Feld. Roman. Göttingen: Steidl.

_ 1996: Avarammille aloille. Suomentanut Oili Suominen. Helsinki: Tammi.

Kallmeyer, Werner - Titttula, Liisa 2003: Strategien für den Umgang mit allgemeinen sozialen Charakterisierungen - am Beispiel von Interviews zur deutsch-finnischen Wirtschaftskommunikation. - Ewald Reuter \& Marja-Leena Piitulainen (toim.), Internationale Wirtschaftskommunikation auf Deutsch. Die deutsche Sprache im Handel zwischen den nordischen und den deutschsprachigen Ländern s. 255-297. Bern: Peter Lang.

Nuolijärvi, Pirkko - Titttula, LiIsa 200oa: Presidenttiehdokkaiden puhetyylit persoonan ilmentäjinä. - Politiikka 42 s. $164-179$.

— 200ob: Televisiokeskustelun näyttämöllä. Televisioinstitutionaalisuus suomalaisessa ja saksalaisessa keskustelukulttuurissa. Helsinki: Suomalaisen Kirjallisuuden Seura.

_ 2001: "Rakas Tarja” ja ”Hyvä ystävä". Puhuttelu minän ja sosiaalisten suhteiden esittämisen keinoina televisiokeskustelussa. - Virittäjä 105 s. $580-601$.

Oittinen, Ristta 1993: I Am Me - I Am Other. On the Dialogics of Translating for Children. Acta Universitatis Tamperensis. Tampereen yliopisto.

Steuer, Outi - Timttula, Lissa 2014: MOT Saksa-suomi-saksa-taloussanakirja. Helsinki: Kielikone.

Tirt tula, LiısA 2017: Politiikan kielen analyysia yleistajuisesti. - Virittäjä 121 s. 464-468. https://doi.org/10.23982/ vir.65072.

Tiittula, Liisa - Nuolijärvi, Pirkko 2013: Puheen illuusio suomenkielisessä kaunokirjallisuudessa. Helsinki: Suomalaisen Kirjallisuuden Seura.

\title{
Evaluoiminen opettajan työvälineenä suomalaisessa koulussa
}

Pilvi Heinonen: Evaluointi opettajan vuorovaikutustoimintana. Osallistujuuden ulottuvuuksia luokkahuoneessa. Helsinki: Helsingin yliopisto 2017. $226 \mathrm{~s}$.

ISBN 978-951-51-3723-4.
Pilvi Heinosen väitöskirja Evaluointi opettajan vuorovaikutustoimintana: Osallistujuuden ulottuvuuksia luokkahuoneessa käsittelee evaluointia toimintana, jonka opettaja rakentaa kehumalla, asemoimalla ti- 
lanteen toimijat ja kaiuttamalla oppilaiden vuoroja. Evaluoinnin avulla hän ohjailee oppilaan toimintaa, osoittaa meneillään olevan toiminnan relevanssia ja määrittää toiminnan rajoja. Heinosen väitöskirja tarjoaa pedagogisia välineitä tai jopa pedagogisen vuorovaikutuksen mallinnuksia opetuksesta ja opetusvuorovaikutuksesta kiinnostuneille lukijoille. Tutkimus on arvioni mukaan ansiokas, joten teos varmasti palkitsee lukijansa - joistakin rakenteellisista raskauksistaan huolimatta.

Tutkimuksen pääaineisto koostuu neljästä historian ja yhteiskuntaopin ja viidestä äidinkielen ja kirjallisuuden oppitunnista, jotka on tallennettu peruskoulun yhdeksänneltä luokalta. Aineiston suhteen ollaan suomalaisen yhteiskunnan yhden peruspilarin, peruskoulutuksen, ytimessä. Lisä- tai tukiaineistona analyysejaan testatakseen tekijä on käyttänyt yhteensä kuutta äidinkielen ja kirjallisuuden oppituntitallennetta yläkoulusta ja lukiosta. Tämä aineisto on peräisin Keskusteluntutkimuksen arkistosta.

Heinonen ei ole päästänyt itseään tutkimuksessa helpolla. Evaluoiminen on erittäin monimutkainen ilmiö. Ensinnäkin evaluointi on pystyttävä tunnistamaan: mikä tahansa vuoro ei tietenkään ole evaluointia. Toiseksi se vaatii toimintana tietynlaisen kontekstin tullakseen tulkituksi evaluoinniksi. Evaluoijalla täytyy esimerkiksi olla auktoriteettia ja sellainen rooli, jossa hänen arvottavilla sanomisillaan on merkitystä. Toki arjessakin ihmiset voivat arvioida ja arvottaa toisiaan, mutta kyse ei välttämättä ole evaluoinnista.

Erityisen mutkikkaaksi evaluoinnin tutkimus muuttuu luokkahuonekontekstissa, jossa opettajan institutionaaliseen rooliin kuuluu lähtökohtaisesti oppimisen arvioiminen. Kun vielä uusimmissa opetussuunnitelman perusteissa korostetaan niin kutsutun online-arvioinnin tärkeyttä, on selvää, että luokkahuonevuorovaikutus on täynnä monenlaista evaluointia. Työn suurimpana haasteena on- kin ollut löytää evaluoivat vuorot ja niiden tehtävät ja erottaa ne muusta luokkahuoneessa tapahtuvasta vuorovaikutuksesta kontekstissa, jossa mikä tahansa opettajan toiminta voitaisiin potentiaalisesti nähdä evaluointina. Kärjistäen voisi sanoa, että on turha tutkia evaluoimista, koska kaikki on sitä. Toisaalta juuri siksi sitä pitää tutkia. Heinonen on ollut tietoinen tästä haasteesta ja käsitellyt sitä kypsästi ja perusteellisesti pohtien - ja selvinnyt haasteestaan. Analyysilukujen argumentaatiota seuratessaan lukija on toisinaan kovilla, koska työssä osoitetaan evaluoinneiksi myös sellaisia toimintoja, joita ei aiemmin ole sellaisiksi ajateltu. Tämä on kuitenkin kirjan parasta antia; konventionaalisissa keinoissa pysytteleminen olisi tuottanut lähinnä vanhastaan tuttua tietoa.

Heinosen tutkimus rakentuu väitöskirjoille tyypilliseen tapaan. Johdantoa seuraa evaluointia ja sen tutkimusta taustoittava luku, kolme analyysilukua ja loppuluku. Vaikka tutkimus on korkeatasoinen, se ei välttämättä sellaisenaan sovellu opettajille suunnatuksi oppaaksi tai työn kuvaukseksi. Olisi hienoa, jos Heinonen työstäisi tulostensa pohjalta yleistajuisemman julkaisun.

Haastetta lukemiseen tuovat erityisesti analyysiluvut, joissa analyysit kärsivät kauttalinjaisesta esimerkkien referoinnista ja toistosta. Tästä ei voi kuitenkaan väitöskirjan kyseessä ollen oikeastaan moittia tekijää, sillä keskustelunanalyysin menetelmäperinne näyttää kantavan mukanaan joitain ongelmallisia piirteitä, yhtenä juuri esimerkkien referointi. Kun analyysiluvut on jäsennetty erilaisten evaluointityyppien - kehuvan, toimijaviitteisen ja kaiuttavan - eikä niiden pedagogisten funktioiden mukaan, ratkaisu on synnyttänyt työhön jonkin verran sisällöllistä päällekkäisyyttä ja toistoa. Kuten tekijä itsekin sanoo, kehuvaa evaluointia voi pitää ensisijaisesti toiminnon kategoriana, toimijaviitteisyyttä syntaksin ja muodon kategoriana ja kaiutusta vuorovaikutuk- 
sen kategoriana. Kun empiirisen analyysin jäsennys perustuu siis hyvin erilaisiin toiminnan tasoihin, analyysin seuraaminen vaatii tarkkuutta. Toisaalta, jos analyyttinen osio olisi jäsennelty opettajan pedagogisten toimintojen mukaan, Heinosen jotkin tutkimustulokset olisivat nousseet vahvemmin esille. Tällöin tekijän tavoite korostaa evaluointia nimenomaan osallistujien yhteisenä, paikallisesti vuorovaikutustilanteessa syntyvänä toimintana valmiiden toimintamallien sijaan olisi kuitenkin kärsinyt.

Opettajan käyttämät evaluoinnit on siis jäsennetty kolmeksi vuorotyypiksi ja toiminnaksi. Luvussa 3 käsiteltävillä kehuvilla evaluointivuoroilla opettaja osoittaa oppilaan toiminnan relevantiksi. Toimijaviitteisillä evaluointivuoroilla (luku 4) opettaja poimii keskiöön tietyn oppilaan tai tiettyjen oppilaiden toiminnan ja ohjaa sitä. Kaiuttavassa evaluointivuorossa, jota käsitellään luvussa 5, opettaja käyttää oppilaan jo sanomaa resurssinaan. Rakenteidensa puolesta vuorotyypit on helppo erottaa toisistaan, mutta funktioidensa osalta ne menevät osin päällekkäin ja limittäin. Esimerkiksi kaiutusluvussa tarkastellaan myös toimintoja (esim. kaiutus resurssina "oppilaan kysymyksen relevanssin osoittamiseen" tai "oppilaan osallistamiseen").

Kaikkein prototyyppisimpien, "vanhastaan tunnettujen" kehuvien evaluointien tehtävät on helpoin hahmottaa. Tällaisia tyypillisesti niin kutsutun opettajavetoisen kyselysyklin osana toimivia kehuvia vuoroja on tutkittu opetusvuorovaikutuksessa paljon. Koko syklistä on tullut suorastaan hegemoninen ja yksinomainen opetuksen vuorovaikutusmalli, jossa opettaja kysyy, oppilas vastaa ja opettaja kuittaa vastatun kehulla oikeanlaiseksi. Heinonen on tässä työssä purkanut tämän syklin yksioikoisuuden ja näyttänyt, ettei evaluointeja ole vain tuossa, oppilaan vastausta evaluoivassa asemassa. Sen sijaan evaluoinnit ovat nimenomaan ja erityisesti reaktioita oppi- laiden aloitteisiin, eivätkä ne suinkaan ole rakenteeltaan oletetun homogeenisia. On ollut järkevää ponnistaa klassikosta siitä huolimatta, että osoittaa sen vanhentuneisuuden. Samalla tekijä on antanut tälle perussyklille ja sen tutkijoille heille kuuluvan tunnustuksen viemällä kuitenkin syklin tarkastelua pidemmälle.

Toisin kuin kehuvien vuorojen, toimijaviitteisiksi analysoitujen evaluointivuorojen pedagogisia funktioita lukijan täytyy hiukan kaivella analyyseista rivien välistä. Tekijän esille nostamia institutionaalisen työnjaon ja oppilaan velvollisuuksien rajojen valvomista tai oppilaan oletetun ja kuvitellun toiminnan rajojen osoittamista voitaisiin jatkaa "pedagogisella jatkumolla" pidemmälle: voisiko rajojen valvominen toimia järjestyksen tai työrauhan ylläpitäjänä tai lopulta yhtä lailla oppilaiden osallistajana ja keinona käsitellä näiden toimintaa relevanttina? Kaiutusvuorojen pedagogisia funktioita ei näy kirjan dispositiotasolla lainkaan. Tämä ei kuitenkaan tarkoita, etteikö kirjasta näitä pedagogisia funktioita löytyisi. Tekijä esimerkiksi kuvaa kaiutussekvenssejä siirtyminä huumorimoodiin, jonka varassa voidaan paitsi moittia osallistujia myös käsitellä noita moitteita ja ylläpitää vuorovaikutustilanteen järjestystä ja rauhaa. Huumorimoodin pedagogista funktiota olisi voinut analysoida vielä syvemminkin, esimerkiksi tarkastelemalla sellaisia toimintoja kuin rohkaiseminen tai muissa analyysiluvuissa käsitelty osallistaminen. Olisin kaivannut toimintojen nostamista kirjassa dispositiotasolle ja eksplisiittisemmin näkyviksi, koska niitähän työssä on tarkasteltu.

Erilaisista luokitteluperusteista voi seurata myös se, että lukijan on vaikea nähdä joitain opettajan vuoroja lainkaan evaluoivina: kun yhdessä luvussa pääperuste evaluoinnille on vuoron sisällön ja rakenteen liitto, kuten kehussa, toisessa luvussa vuoro määrittyy evaluoinniksi juuri sekventiaalisen, keskustelun yleiseen kulkuun perustuvan paikan tai opettajan institutio- 
naalisen roolin perusteella. Joidenkin tulkintojen äärelle lukijaa olisi voinut taluttaa tiiviimmin perustellen. Paikoin lukija saa miettiä hyvin tarkkaan, millä perusteella tämä vuoro nyt olikaan evaluointi.

Kuitenkin tällainen ponnistelu on väistämätöntä silloin, kun ollaan uudenlaisen ajattelun tai näkemyksen äärellä. Teoksen kaikki yhteenvetoluvut, myös analyysiosassa, ovat hyvin selkeitä ja esittävät kulloisenkin ilmiön tyhjentävästi. Tässä työssä ollaan näennäisesti tutun kontekstin, aineiston ja toiminnan sijaan tekemisissä hyvinkin uudenlaisten toiminnan tutkimuksen näkökulmien kanssa. Kirjan luettuaan näkee evaluoinnin eri silmin kuin ennen, ja se on tutkimukselle ja teokselle suuri meriitti. Heinosen aihe on erittäin haastava, mutta tekijä on onnistunut rajaamaan tutkimusongelman perustellun ytimekkäästi. Tutkimus tuottaa uutta tietoa yhteiskunnalli- sesti tärkeästä aiheesta, jonka tieteellinen käsittely on pitkään kulkenut samaa uraa kyseenalaistamatta aiempaa tutkimusta. Tämän tuloksena luokkahuonevuorovaikutuksen tutkimuskentällä on syntynyt paljon pitkälti vain aiempaan tutkimukseen pohjaavaa vuorovaikutuksen kuvailua. Heinosen tutkimustulokset ovat ansiokkaita, ja niitä on mahdollista soveltaa melko suoraan myös opettajankoulutukseen tai jopa mallintaa pidemmälle, vaikkapa osaksi suomalaista koulutusvientiä. Teosta voi suositella jokaiselle opettajalle ja sellaiseksi aikovalle.

$$
\begin{array}{r}
\text { MIA HALONEN } \\
\text { etunimi.m.sukunimi@jyu.fi } \\
\text { Kirjoittaja on yliopistotutkija } \\
\text { Soveltavan kielentutkimuksen keskuksessa } \\
\text { Jyväskylän yliopistossa ja suomen kielen } \\
\text { dosentti Helsingin yliopistossa. } \\
\text { Hän toimi Heinosen vastaväittäjänä. }
\end{array}
$$

\section{Merkkiteos itämerensuomalaisten esihistorian tutkimuksessa}

Valter Lang: Läänemeresoome tulemised. Muinasaja teadus 28. Tartu Ülikooli Kirjastus 2018. 320 s. ISBN 978-994-977-662-7.

Etelänaapurissamme ilmestyi itsenäisyyden satavuotisjuhlan aikoihin harvinaislaatuinen teos: Tarton yliopiston arkeologian professori Valter Langin monografia itämerensuomalaisten kansojen ja kielten esihistoriallisesta syntyprosessista. Erityiseksi kirjan tekee se, että siinä on yhden tutkijan voimin koottu monitieteisen tutkimuksen viimeisimmät - osin vie- läpä aiemmin julkaisemattomat - tulokset johdonmukaiseksi ja yleistajuiseksi kokonaisesitykseksi. Kirjan laajaan ja monipuoliseen lähdeaineistoon kuuluu tutkimuksia niin kielitieteen, arkeologian, historian, ilmastotieteen kuin paleogenetiikan aloilta. Humanistisen tutkimuksen parhaitten perinteitten mukaisesti kirjoittaja on hyödyntänyt kaikilla tutkitun alueen valtakielillä - viroksi, suomeksi, ruotsiksi, tanskaksi, saksaksi, englanniksi, liettuaksi, latviaksi ja venäjäksi - kirjoitettuja lähteitä. Läänemeresoome tulemised 